\title{
Characteristics and mechanisms of arsenic behavior during the microbial oxidation-reduction of iron
}

\author{
W. Xiu ${ }^{1}$, H.M. Guo ${ }^{1,2}$, X.N. Yu², W.J. Yuan ${ }^{2} \&$ T.T. Ke ${ }^{2}$ \\ ${ }^{1}$ State Key Laboratory of Biogeology and Environmental Geology, China University of Geosciences, \\ Beijing, P.R. China \\ ${ }^{2}$ School of Water Resources and Environment, China University of Geosciences (Beijing), Beijing, P.R. China
}

\begin{abstract}
The (bio)geochemical cycling of arsenic (As) and iron (Fe) is generally coupled in high As groundwater. However, characteristics and mechanisms of As sequestration-release behavior during formationreduction of biogenic Fe(III) minerals (bio-FeM) are poorly understood. The Pseudogulbenkiania sp. strain 2002 induced the formation of binary bio-FeM, facilitating As immobilization compared to single Fe(III) minerals. Net As release was found during reduction of binary bio-FeM by Shewanella oneidensis strain MR-1, which was affected by secondary iron mineral formation and competitive adsorption. We suggested that bio-FeM deserve more attention due to their outstanding potential roles in controlling As behavior in aquatic systems.
\end{abstract}

\section{INTRODUCTION}

High arsenic (As) groundwater (As concentration > $\left.10 \mu \mathrm{g} \mathrm{L}^{-1}\right)$ is one of the major worldwide concerns. Arsenic (bio)geochemical cycling is often coupled to the cycling of iron (Fe) (Zhu et al., 2017). For instance, natural ferric (hydro)oxides, mainly consisting of various biogenic Fe(III) minerals (bio-FeM), possess high sorption reactivity, which have the potential to coprecipitate or adsorb As (Feris, 2005; Xiu et al., 2015; Xiu et al., 2016; Sowers et al., 2017). Whereas, dissimilarly reductive dissolution of Fe(III) (hydro)oxides is of utmost importance in controlling As enrichment in groundwater under reducing condition (Islam et al., 2004; Postma et al., 2010; Schaefer et al., 2017). However, characteristics and mechanisms of As sequestration-release behavior during the formationreduction of biogenic $\mathrm{Fe}(\mathrm{III})$ minerals are poorly understood. The Objectives of this study are to (i) characterize As sequestration by biogenic Fe(III) minerals as well as related mechanisms of As sequestration; (ii) explore the character and mechanisms of As release during bio-reduction of biogenic Fe(III) minerals.

\section{METHODS/EXPERIMENTAL}

\subsection{Sources of microbes}

The anaerobic Fe-oxidizer, Pseudogulbenkiania sp. strain 2002 , was retrieved from lab stock ( $20 \%$ glycerol at $-80^{\circ} \mathrm{C}$, Geomicrobiology Lab at the China University of Geosciences, Beijing) and routinely cultivated at $30^{\circ} \mathrm{C}$ using freshwater basal medium with nitrate and acetate as electron acceptor and donor, respectively.
The facultative dissimilarly iron reducer, Shewanella oneidensis MR-1 was routinely cultured aerobically in Luria-Bertani (LB) broth $(\mathrm{pH}=7.0)$ at $30^{\circ} \mathrm{C}$. Once cell growth reached the mid to late log phase, centrifuged in anaerobic chamber (filled with $\mathrm{N}_{2} / \mathrm{H}_{2}, 92.5 \% / 7.5 \%(\mathrm{v} / \mathrm{v})$, Coy Laboratory Products, USA), washed three times with deoxygenated bicarbonate buffer $\left(2 \mathrm{~g} \mathrm{~L}^{-1} \mathrm{NaHCO}_{3}\right.$ and $0.08 \mathrm{~g} \mathrm{~L}^{-1} \mathrm{KCl}$, $\mathrm{pH}=7.0$ ) to remove residual $\mathrm{LB}$, and resuspended in buffer to a final concentration of $\sim 2 \times 10^{8}$ cells mL $^{-1}$. In selected treatments, AQDS (Sigma) was added separately.

\subsection{Experiential setups}

To obtain the As-containing bio-FeM, anaerobic cultures with $1 \mathrm{mg} \mathrm{L}^{-1} \mathrm{As}(\mathrm{V})$ and approximately initial $3.0 \mathrm{mM} \mathrm{Fe}$ (II) (initial molar ratio of $\mathrm{Fe}(\mathrm{II}) / \mathrm{As}(\mathrm{V})$ around 225) were incubated with later log-phase cells of strain $2002(5 \%, \mathrm{v} / \mathrm{v})$. The bio-FeM was sampled by repeated centrifugation (1000 rpm for $10 \mathrm{~min}$ ), following by rinsing with deionized water, dried in an anaerobic glove box until analyzed within one week. Reduction of bio-FeM was conducted in bicarbonate buffer containing bio-FeM $\left(\sim 100 \mathrm{mg} \mathrm{mL}^{-1}\right)$ and MR1 cells $\left(\sim 2 \times 10^{8}\right.$ cells $\left.\mathrm{mL}^{-1}\right)$. Tubes were purged with $\mathrm{N}_{2} / \mathrm{CO}_{2}$ gas mix (80:20) and sealed with thick butyl rubber stoppers. The control consisted of one tube that received $1 \mathrm{~mL}$ of sterile bicarbonate buffer in place of MR-1 cells.

\subsection{Analytical methods}

Suspension were anoxically taken at different time intervals and divided into two equivalents. One was filtered with $0.22 \mu \mathrm{m}$ membrane filter, and analyzed for dissolved As species, dissolved Fe species. The other 

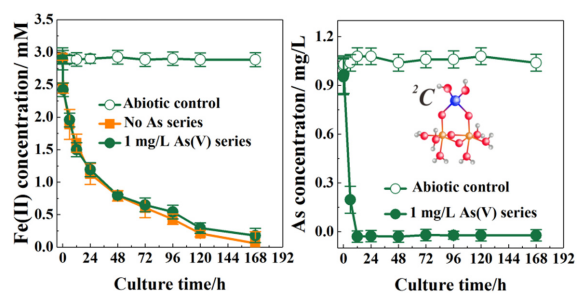

Figure 1. Changes of dissolved As and Fe(II) during strain 2002-induced Fe(II) oxidation: (left) changes of dissolved $\mathrm{Fe}(\mathrm{II})$; (right) changes of dissolved As.

was used to monitor the progress of Fe(III) reduction, following the 1,10-phenanthroline assay. The bioFeM were sampled and analyzed by scanning electron microscopy (SEM), X-ray photoelectron spectroscopy (XPS), frontier transform IR spectra (FTIR), X-ray diffraction (XRD), and As and Fe K-edge XANES and EXAFS.

\section{RESULTS AND DISCUSSION}

\subsection{As immobilization during the formation of biogenic Fe(III) minerals}

Results showed that a rapid decrease in $\mathrm{Fe}(\mathrm{II})$ concentration was observed in early stage (before $24 \mathrm{~h}$ ) and thereafter, $\mathrm{Fe}(\mathrm{II})$ concentrations dropped relatively placid after $24 \mathrm{~h}$, forming the mixture of two-line ferrihydrite and goethite. Simultaneously, $\mathrm{As}(\mathrm{V})$ was efficiently removed from solutions through adsorption onto and/or co-precipitation with biogenic ferrihydrite-goethite biminerals (Fig. 1), forming binulear bidentate corner sharing As-Fe complexes $\left({ }^{2} C\right)$. The $\mathrm{As}_{\text {immobilized }} / \mathrm{Fe}_{\text {precipitated }}$ at the end of incubation $(168 \mathrm{~h})$ achieved 0.005 , which was higher than that in poorly crystalline or even amorphous biogenic $\mathrm{Fe}(\mathrm{III})$ oxides under similar condition. No detectable redox transformations of $\mathrm{As}(\mathrm{V})$ were observed.

\subsection{Reduction of biogenic Fe(III) minerals}

Result showed that $\mathrm{Fe}$ (III) reduction occurred when log phase of MR-1 was reached. A rapid increase in Fe(II) concentration was observed in early stage $(<72 \mathrm{~h})$, and thereafter dropped, possibly due to the formation of secondary iron minerals. Simultaneously, As release occurred before $24 \mathrm{~h}$ (mainly As(V) resulting from iron reduction), and then released As was re-immobilized into secondary iron minerals, and finally As was mobilized from secondary iron minerals possibly via competitive adsorption) (Fig. 2).

\section{CONCLUSIONS}

The Pseudogulbenkiania sp. strain 2002 induced the formation of binary bio-FeM, facilitating As immobilization compared to single $\mathrm{Fe}(\mathrm{III})$ minerals. Net As release was found during reduction of binary bio-FeM by Shewanella oneidensis strain MR-1, affected by secondary iron mineral and competitive adsorption.
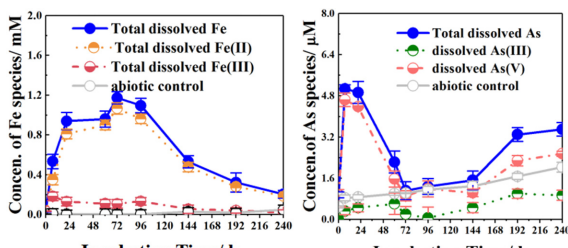

Incubation Time/ h

Incubation Time/ h

Figure 2. Changes of dissolved As and $\mathrm{Fe}(\mathrm{II})$ during MR-1-induced Fe(III) reduction: (left) changes of dissolved Fe species; (right) changes of dissolved As species.

\section{ACKNOWLEDGEMENTS}

The study is financially supported by the National Natural Science Foundation of China (Nos. 41702272, $41672225,41222020$ and 41172224$)$ and the Fundamental Research Funds for the Central Universities (No. 53200759026, 2652013028).

\section{REFERENCES}

Ferris, F.G. 2005. Biogeochemical properties of bacteriogenic iron oxides. Geomicrobiol. J. 22(3-4): 79-85.

Guo, H., Ren, Y., Liu, Q., Zhao, K. \& Li, Y., 2013. Enhancement of arsenic adsorption during mineral transformation from siderite to goethite: mechanism and application. Environ. Sci. Technol. 47(2): 1009-1016.

Hohmann, C., Morin, G., Ona-Nguema, G., Guigner, J.M., Brown Jr, G.E. \& Kappler, A. 2011. Molecular-level modes of As binding to Fe (III)(oxyhydr) oxides precipitated by the anaerobic nitrate-reducing Fe (II)-oxidizing Acidovorax sp. strain BoFeN1. Geochim. Cosmochim. Acta 75(17): 4699-4712.

Islam, F.S., Gault, A.G., Boothman, C., Polya, D.A., Charnock, J.M., Chatterjee, D. \& Lloyd, J.R. 2004. Role of metal-reducing bacteria in arsenic release from Bengal delta sediments. Nature 430(6995): 68 .

Postma, D., Jessen, S., Hue, N.T.M., Duc, M.T., Koch, C.B., Viet, P.H., Nhan, P.Q. \& Larsen, F. 2010. Mobilization of arsenic and iron from Red River floodplain sediments, Vietnam. Geochim. Cosmochim. Acta 74(12): 3367-3381.

Schaefer, M.V., Guo, X., Gan, Y., Benner, S.G., Griffin, A.M., Gorski, C.A., Wang, Y. \& Fendorf, S. 2017. Redox controls on arsenic enrichment and release from aquifer sediments in central Yangtze River Basin. Geochim. Cosmochim. Acta 204: 104-119.

Sowers, T.D., Harrington, J.M., Polizzotto, M.L. \& Duckworth, O.W. 2017. Sorption of arsenic to biogenic iron (oxyhydr) oxides produced in circumneutral environments. Geochim. Cosmochim. Acta 198: 194-207.

Xiu, W., Guo, H., Liu, Q., Liu, Z. \& Zhang, B. 2015. Arsenic removal and transformation by Pseudomonas sp. strain GE-1-induced ferrihydrite: co-precipitation versus adsorption. Water Air Soil Poll. 226(6): 167.

Xiu, W., Guo, H., Shen, J., Liu, S., Ding, S., Hou, W., Ma, J. \& Dong, H. 2016. Stimulation of Fe (II) oxidation, biogenic lepidocrocite formation, and arsenic immobilization by Pseudogulbenkiania sp. strain 2002. Environ. Sci. Technol. 50(12): 6449-6458.

Zhu, Y.G., Xue, X.M., Kappler, A., Rosen, B.P. \& Meharg, A.A. 2017. Linking genes to microbial biogeochemical cycling: lessons from arsenic. Environl. Sci. Technol. 51(13): 7326-7339. 